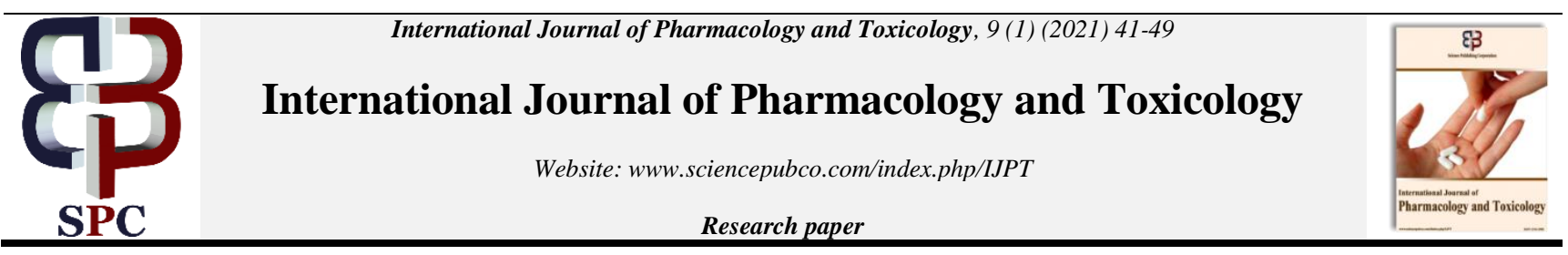

\title{
The protective action of ethanolic stem bark extract of Carissa edulis (VAHL) Apocynaceae against carbon tetrachloride Hepatotoxicity in rats
}

\author{
Y.Y. Izam ${ }^{1 *}$, B.B. Bukar ${ }^{1}$ \\ ${ }^{1}$ Department of Pharmacology, Faculty of Pharmaceutical Sciences, University of Jos \\ *Corresponding author E-mail: izamyo@unijos.edu.ng
}

\begin{abstract}
Background: Carissa edulis is generally used for the treatment of diverse ailments, but little or no interest has been shown on its hepatoprotective properties. This research work was aimed at evaluating the safety and claimed hepatoprotective activity of Carissa edulis. Method: For the intent of data collection, the method of Li et al., 2011 was used. In this method animals were treated with (250,500 and $1000 \mathrm{mg} / \mathrm{kg}$ ) of stem bark extract. The extract was given daily by gavage to the animals for 28 consecutive days. The $50 \% \mathrm{v} / \mathrm{vCCl} 4$ and olive oil was gavaged through gastric tube twice a week. The tests conducted were liver function test, liver antioxidant enzymes test, lipid profile test as well as Histopathological assessment of the liver sections.

Results: Results of the study revealed that the markers in the animal treated with $\mathrm{CCl}_{4}$ were significantly higher than the normal control at $(\mathrm{P}<0.05)$. While blood samples from animals treated with the stem bark extracts were significantly lower than the $\mathrm{CCl}_{4} \mathrm{group}$ $(\mathrm{P}<0.05)$.

Conclusion: These results imply that the ethanolic stem bark extract of Carissa edulis have a protective effect against $\mathrm{CCl}_{4}$ induced hepato - cellular injury.
\end{abstract}

Keywords: Carissa edulis; Hepatoprotective Activity; Ethanolic Stem Bark Extract; Hepatic Damage; $\mathrm{CCl}_{4}$

\section{Introduction}

\subsection{Hepatotoxicity}

The liver plays a vital role in transforming and clearing chemicals and is at risk of toxicity from these agents. Certain medicinal agents when taken in overdose and sometimes even in therapeutic range may damage the liver, other chemical agents such as those in the laboratories and industries, natural chemicals can also stimulate Hepatotoxicity. More than 900 drugs have been associated with liver injury (Friedman et al., 2003). Drug induced liver injury account for 5\% of all hospital admission and 50\% of all acute liver injury (Ostapowicz et al., 2002, McNally \& Peter 2006). The precise mechanism of drug induced liver injury remains basically unknown but it appears to involve two pathways namely, direct-Hepatotoxicity and adverse immune reaction.

Drug induced liver injury emanates from the bio activation of drugs to chemically reactive metabolites which have the ability to be integrated with cellular macromolecules such as protein, lipids and nucleic acid, resulting to protein dysfunction, lipid per oxidation, DNA damage and oxidative stress (Lee 2003, Deng et al., 2009). Hepatocellular dysfunction and cell death also have the capability to initiate immunological reactions, as well as both innate and adaptive immune responses. It has been established that different inflammatory cytokines such as tumor necrosis factors (TNF) - interferon (IFN)-y, and interleukin (IL) B formed during liver injury are implicated in promoting tissue damage (Ishida et al., 2002). Innate immune cells are also the main source of IL-6, IL-1O, and prostaglandins. All these cytokines have been discovered to posses' hepatoprotective roles (Masubuchi et al., 2003).

\subsection{Background and justification}

Liver injury related with the consumption of herbal medicine is known as Herb-induced liver injury (HILI), which occurs infrequently in only a few susceptible individuals (Pantano et al., 2006, Pantano et al., 2017). The clinical presentation of HILI matches those of Druginduced liver injury (DILI) (Pantano et al., 2016). In addition HILI and DILI share common characteristics, as both cases are caused by chemical components that are formed either by natural or synthetic processes. These natural and synthetic chemicals are foreign to the body and have need of metabolic breakdown to eliminate. However, in the process of metabolism, substances that are toxic to the kidney could be formed (Frenzel \&Teschke 2016). Herbs like Aloe vera, Black cohosh, Cascara, Chaparral, Comfrey, Ephendra or Kava could lead to toxic liver diseases (Marie 2015).

DILI incidence according to past published data was between 1 in 10,000 and 1 in 100,000. Nevertheless, more recent studies reported a higher incidence (Bjornsson 2015). There are numerous registries both in Western and Asian Countries which have provided valuable 
information as regards the etiology, pathogenesis as well as the clinical presentation diagnosis and management of DILI. Some population studies in fact revealed an annual incidence of 19.1 cases per 100,000 inhabitants in Iceland (Bjornsson et al., 2013) and 13.9 cases per 100,000 inhabitants in France with hospitalization of 12\% and mortality of 6\% 500 in deaths per annum in French widespread population (Saro et al., 2000). Numerous drugs potentially cause DILI, but the most commonly involved are antibiotics which according to DILI network in the USA stand for about $46 \%$ of DILI cases (Chalassani et al., 2008).

Carissa edulis previously identified as C. Pubescence belongs to the family Apocynaceae, (Irvine 1961, Hutchinson \& Dalziel 1963). The plant is usually known among Hausa people in Northern Nigeria as "Cizaki" and in Somalia as Adishawel. The English name of the plant is Arabic numnum. There are other common names such as: endelkoring-noeminaem (Africana), 'emir' (Arabic) muyonzo (Luganda), 'mianoa-mboo, (Swahili) and impambala myoloko, (Sofowara 1986).

The plant parts are used in ethno medicine for a large array of illnesses such as epilepsy, headache, chest complaint, gonorrhea, syphilis, rheumatism, rabies as well as diuretic. Other Folkloric indications of Carissa edulis include fever, sickle cell anemia and hernia (Ibrahim 1997). Carissa edulis is also being used as a source of dye (Oliver 1960, Irvine 1961, Burkil 1985, Banker \& Verma 1987, Omino \& Kokwaro1993).

Even though there are no adverse effect reports on Carissa edulis herbal medicine (Ahmad \& Odin 2017, Hanan \& Hassan 2017). It has been employed as a traditional medicine in Kenya for the treatment of different ailment without any reported side effect. (Adil et al., 2003, Kabeinei et al., 2011). It was alleged that this plant could virtually cure all forms of human ailment including cancer, diabetes and HIV-AIDS (Zephania 2011). The petroleum ether, ethyl acetate and aqueous extract of Carissa edulis have a marked potency for lowering the blood pressure in rats at a dose dependent manner (Alyoussef \& Hassan 2010). Roots extracts of Carissa edulis are used for the treatment of numerous pathological states including inflammatory disorders. Oral administration of Carissa edulis extracts $(30-300 \mathrm{mg} / \mathrm{kg}$ P.O significantly inhibited carrageen an-induced foot edema through maximum inhibition of $62+9.1 \%$ and $66.4+.8 \%$ respectively (Woode et al., 2007). The extract in addition scavenged DPPH (Diphenylpicryihydrazyl) and prevented lipid per oxidation in rat's brain homogenate. These results suggest that the alcoholic extract of Carissa edulis possibly exert in vivo inflammatory and antioxidant properties which may contribute to its activity.

Carissa edulis is widely used for the treatment of various ailments but little or no interest has been shown in its hepatoprotective properties. Hence the needs for a hepatoprotective study of this plant to ascertain its effect on the liver because the treatment and management of this organ results in more economic problems.

\section{Method}

\subsection{Animals}

Wistar albino rats (male) weighing between (120-220 grams) acquired from experimental animal house of the Department of Pharmacology University of Jos was used for the study. The rats were supplied with standard animal pellets (Pfizer Feeds Nigeria), given water $a d$ libitum and maintained in a well ventilated room.

\subsection{Collection identification and authentication of Carissa edulis}

The stem bark of Carissa edulis was collected from Fursum East, Jos East Local Government Area of Plateau State, on the $7^{\text {th }}$ December, 2016. The plant was identified and authenticated by Mr. J.J Azila of the Federal College of Forestry Jos. A voucher specimen number UJ/PCG/HSP/95A09 was issued and the specimen placed in the Faculty of Pharmaceutical Sciences University of Jos Herbarium for reference.

\subsection{Preparation of Carissa edulis extract}

The stem bark was detached from the whole plant and air dried at room temperature for fourteen (14) days. The dried part was powdered with mortar and pestle and sieved with 29 mesh size. The powder was soxhlet extracted with $700 \mathrm{ml} 70 \%$ v/v ethanol for 72 hours. The resultant filtrate was evaporated to dryness on steam bath at $40^{\circ} \mathrm{C}$ to give brownish extract that was stored up in air tight containers and preserved at $4^{\circ} \mathrm{C}$ until required for use.

\subsection{Preliminary Phytochemical studies of Carissa edulis extract}

Phytochemical evaluation of the ethanolic stem bark of Carissa edulis was carried out to identify the presence or absence of secondary metabolites (Alkaloids, Anthraquinones, Cardiac glycosides, Carbohydrates, Flavonoids, Saponins, Tannins and Steroids via standard methods (Trease \& Evans 1989).

\subsection{Determination of $\mathrm{LD}_{50}$ of Carissa edulis}

The acute toxicity study of the stem bark extract was determined using the method of Lorke (1983). This was done in two phases. In the initial phase (phase 1), nine rats were randomly divided into three groups of three rats per-group and were administered 10, 100 and $1000 \mathrm{mg} / \mathrm{kg}$ of the extract of Carissa edulis orally (via a cannula) respectively. The rats were observed for signs of adverse effects and death for 24 hours. Based on the outcome of the phase one study, the procedures was repeated using another set of three rats randomly divided into three groups of one rat each, administered 1600,2900 and $500 \mathrm{mg} / \mathrm{kg}$ body weight of the extracts respectively for 14 days the rats were observed for signs of toxicity which consist of but not limited to paw ticking, salivation, stretching, rubbing of nose on the floor and wall of the cage, change in body weight and death.

\subsection{Hepatoprotective studies}

The method of ( Li et al., 2011) was adopted for the study. Thirty-six rats were randomly divided into 6 groups of 6 rats each. The groups were: Normal control, standard drug, carbon tetrachloride treated group and the three test groups $(250,500 \mathrm{and} 1000 \mathrm{mg} / \mathrm{kg})$ for the stem bark extract. The standard drug used was Silymarin. 
To study the protective effect against carbon tetrachloride induced chronic hepatic injury Carissa edulis stem bark extract (250, 500 and $1000 / \mathrm{kg}$ body weight) was given daily by oral gavage to animals for 28 consecutive days. The $50 \% \mathrm{v} / \mathrm{vCCl}_{4}$ in olive oil was gavaged through gastric tube to the extract treated groups $(250,500$ and $1000 \mathrm{mg} / \mathrm{kg}$ body weight) twice a week on the third and seventh day of each week for four weeks (The duration of the 28days treatment). Then normal control group were administered distilled water $5 \mathrm{ml} / \mathrm{kg}$ body weight daily for 28 days. Animals of the $\mathrm{CCl}_{4}$ group were given $\mathrm{CCl}_{4}$ twice a week on the third and seventh day of each week and with vehicle on rest of the days for 4 weeks. While the animals of the silymarin standard group were treated with the standard drug silymarin at a dose of $50 \mathrm{mg} / \mathrm{kg}$ daily for 28 consecutive days alongside $\mathrm{CCl}_{4}$ on the third and seventh day of each week through the gastric tube ( Oral route).

On the $29^{\text {th }}$ day each rat was anaesthetized with ethyl ether, the weights of the rats were recorded. The animals were then sacrificed and the blood sample collected from the jugular vein into plain tubes for biochemical evaluation. The biochemical test conducted include: (1) Liver function test which comprises, Alanine Aminotransferase (ALT), Aspartate Transaminase (AST), Albumin (ALB), Alkaline Phosphatase(ALP), Total Protein (TP) and Bilirubin(BIL). (2) Lipid profile test which comprise of, (Total Cholesterol (CHL), High Density Lipoprotein (HDL) and Triglyceride (TRIG). The liver was harvested, trimmed of adherent tissue and preserved in $10 \%$ formaldehyde solution for succeeding histopathological examination. Part of the liver harvested was put into normal saline solution for measurement of Superoxide Dismutase (SOD), Catalase (CAT), Malondialdehyde (MDA), and Glutathione (GHS).

\subsection{Statistical analysis}

The results were expressed as Mean \pm SEM where applicable. The data were subjected to ANOVA (Analysis of Variance) using SPSS software (version 20) and in each stage where ANOVA was significant a post-Hoc test (Fishers least Significant Difference) was carried out. The difference was taken to be statistically significant at $\mathrm{P}<0.05$, after comparing treatment groups with negative control animals.

\section{Results}

\section{Phytochemical screening of the Ethanolic Stem Bark Extracts of Carissa edulis}

The preliminary phytochemical test for the stem bark extracts was positive for saponin tannins, flavonoids, carbohydrates, cardiac glycosides and steroids. Tannins, flavonoids, Carbohydrates and steroids were highly present while alkaloids and anthraquinones were absent.

Table 1: Phytochemical Screening of the Stem Bark of Carissa Edulis

\begin{tabular}{lc}
\hline Constituents & Bark Extract \\
\hline Alkaloids & - \\
Saponins & + \\
Tannins & ++ \\
Flavonoids & +++ \\
Carbohydrates & +++ \\
Cardiac glycosides & + \\
Steroids & +++ \\
Anthraquinones & - \\
\hline
\end{tabular}

Keys:-Negative, + Present.

Determination of LD50 of the stem bark extracts of Carissa edulis in Rats

The extract did not cause mortality at a dose of $5000 \mathrm{mg} / \mathrm{kg}$. The animal was calm, non-aggressive, decreased exploratory activities and no stereotype behavior.

Table 2: Determination of $\mathrm{LD}_{50}$ of the Leaf Extract of Carissa Edulis

\begin{tabular}{llll}
\hline Dose $\mathrm{mg} / \mathrm{kg}$ & $\begin{array}{l}\text { Number of Rats } \\
\text { Used }\end{array}$ & Number of Death & Behavioural Effect \\
\hline 10 & 3 & 0 & $\begin{array}{l}\text { Animals were calm, non-aggressive decreased exploratory activity no stereotyped behaviour. } \\
\text { Animals were calm, non-aggressive, decreased exploratory activities no stereotyped behav- } \\
\text { iour }\end{array}$ \\
100 & 3 & 0 & $\begin{array}{l}\text { Animals were calm, non-aggressive, decreased exploratory activity no stereotyped behaviour } \\
\text { Animal was calm, non-aggressive decreased exploratory activities, no stereotyped behavior }\end{array}$ \\
1000 & 3 & 0 & Animal was calm, non-aggressive, decreased exploratory activities, no stereotyped behavior \\
5000 & 1 & 0 & Animal was clam, non-aggressive, decreased exploratory activities no stereotyped behaviour \\
\hline
\end{tabular}

Effects of the Stem Bark Extract of Carissa edulis on the Body Weight of Rats Treated with $\mathrm{CCl}_{4}$

The study revealed that in the normal control group, there was a significant increase in body weight at day 14(151.38 \pm 4.58$)$, $(155.7 \pm 4.63)$ at day 21 and $(175.50 \pm 7.79)$ at day 28 , from the initial weight $(134.98 \pm 3.38)$ at day 0 . In the $\mathrm{CCl}_{4}$ group, there was a significant increase in weight from initial weight $(127.83 \pm 2.26)$ to $(140.88 \pm 2.33)$ at day 14 to $(149.90 \pm 2.65)$ at day 21 and $(158.01 \pm 3.08)$ at day 28.

In the standard drug group silymarin there was no significant change in body weight. For $250 \mathrm{mg} / \mathrm{kg}$ of the stem bark extract, there was a significant decrease in body weight from $148.85 \pm 5.40$ at day 0 to $129.85 \pm 5.40$ at day $28(\mathrm{P}<0.05)$. For $500 \mathrm{mg} / \mathrm{kg}$ of the stem bark extract there was no significant difference in body weight compared with control $(\mathrm{P}<0.05)$.

For $1000 \mathrm{mg} / \mathrm{kg}$ of the stem bark extract there was a significant increase in body weight from (133.83 \pm 1.51$)$ at day 0 to (140.55 \pm 2.62$)$ at day 7 to $(150.26 \pm 2.53)$ at day $14,(153.01 \pm 2.54)$ at day 21 and $(155.75 \pm 3.36)$ at day 28 .

Table 3:Effect of Ethanolic Stem Bark Extract of Carissa Edulis on Body Weight (g) of Rats Treated with $\mathrm{CCl}_{4}$

\begin{tabular}{lllll} 
& Table 3:Effect of Ethanolic Stem Bark Extract of Carissa Edulis on Body Weight (g) of Rats Treated with CCl & & \\
& 0 & 7 & 14 & 21 \\
\hline Treatment/ Days & $134.98 \pm 3$ & $147.91 \pm 3.98$ & $151.38 \pm 4.58$ & $155.75 \pm 4.63$ \\
\hline Control & $137.40 \pm 3.47$ & $136.71 \pm 3.53$ & $135.18 \pm 3.45^{\mathrm{a}}$ & $172.50 \pm 7.79$ \\
Standard Drug & & & $132.40 \pm 1.81^{\mathrm{a}}$ & $128.53 \pm 2.11^{\mathrm{a}}$ \\
\hline
\end{tabular}




\begin{tabular}{|c|c|c|c|c|c|}
\hline $\mathrm{CCl}_{4}$ & $127.83 \pm 2.26^{\mathrm{b}}$ & $133.33 \pm 2.33^{\mathrm{ab}}$ & $140.88 \pm 2.33$ & $149.90 \pm 2.65^{\mathrm{b}}$ & $158.01 \pm 3.08^{b}$ \\
\hline $250 \mathrm{mg} / \mathrm{Kg}($ Bark $)+\mathrm{CCL}_{4}$ & $148.06 \pm 5.06$ & $161.00 \pm 5.89^{\mathrm{bc}}$ & $163.05 \pm 5.06^{\mathrm{abc}}$ & $148.31 \pm 5.77^{\mathrm{b}}$ & $129.85 \pm 5.40^{\mathrm{ac}}$ \\
\hline $500 \mathrm{mg} / \mathrm{Kg}$ (Bark) $+\mathrm{CCL}_{4}$ & $128.55 \pm 2.87^{b}$ & $140.91 \pm 5.98^{c}$ & $140.98 \pm 5.30^{\mathrm{b}}$ & $130.46 \pm 6.83^{\mathrm{ac}}$ & $120.98 \pm 7.76^{\mathrm{ac}}$ \\
\hline $1000 \mathrm{mg} / \mathrm{Kg}($ Bark $)+\mathrm{CCL}_{4}$ & $133.83 \pm 1.51^{\mathrm{b}}$ & $140.55 \pm 2.62^{c}$ & $150.26 \pm 2.53^{b}$ & $153.01 \pm 2.54^{\mathrm{b}}$ & $155.75 \pm 3.36^{\mathrm{ab}}$ \\
\hline $\operatorname{LSD}(0.05)$ & 10.90 & 11.87 & 11.42 & 14.07 & 15.86 \\
\hline
\end{tabular}

Means tagged with superscript ' $a$ ' are significantly different compared to Normal Control at $\mathrm{p}<0.05$

Means tagged with superscript ' $b$ ' are significantly different compared to Standard Drug at $p<0.05$

Means tagged with superscript ' $c$ ' are significantly different compared to $\mathrm{CCl}_{4}$ at $\mathrm{p}<0.05$

Means tagged with superscript a, b and 'c' are significantly different compared to Normal control, Standard Drug and $\mathrm{CCl}_{4}$ at $\mathrm{p}<0.05$; value are Mean \pm SEM

\section{Effect of Ethanolic Stem Bark Extract of Carissa edulis on Liver Function Indices of Rats Treated with $\mathrm{CCl}_{4}$}

The three concentrations of the stem bark extracts $(250,500$ and $1000 \mathrm{mg} / \mathrm{kg})$ showed level of significance in measure of protection to the rats against $\mathrm{CCl}_{4}$ liver damage with significant decrease in the level of the liver function indices compared to the $\mathrm{CCl}_{4}$ group at $\mathrm{P}<0.05$. In ALT, all the groups $\left(250,500\right.$ and $1000 \mathrm{mg} / \mathrm{kg}$ ) had lower levels of ALT compared to the $\mathrm{CCl}_{4}$ group at (363.60 \pm 60.32$)$ but groups administered $500 \mathrm{mg}$ and $1000 \mathrm{mg}$ of the stem bark extract showed significantly lower level of ALT compared to the $\mathrm{CCl}_{4} \mathrm{group}$

In AST, all the three concentrations of the stem bark extracts were significantly lower than the $\mathrm{CCl}_{4}$ group in a dose dependent manner. In ALP, all the three concentrations of the stem bark extracts were significantly lower than the $\mathrm{CCl}_{4}$ group at (1275.66 \pm 175.21$)$. In ALB, the treatment groups with the lowest concentrations were the normal control, 500 and $1000 \mathrm{mg} / \mathrm{kg}$ of the bark extract having significantly lower level of $(3.91 \pm 0.11)$. In TP, there was no significant difference between the normal control, the $\mathrm{CCl}_{4}$ group and the three extract treated groups. In bilirubin, the lowest value was observed in the groups given $500 \mathrm{mg}$ of the stem bark extract followed by the $\mathrm{CCl}_{4}$ group. The highest level was observed in the standard control group which is significantly higher than the other groups.

Table 4:Effect of the Ethanolic Stem Bark Extract of Carissa Edulis on Liver Function Indices of Rats Treated with $\mathrm{CCl}_{4}$.

\begin{tabular}{lllllll}
\hline Treatments & ALT(U/L) & AST(U/L) & ALB $(\mathrm{g} / \mathrm{L})$ & ALP $(\mathrm{U} / \mathrm{L})$ & TP $(\mathrm{g} / \mathrm{L})$ & BIL $(\mu \mathrm{mol} / \mathrm{L})$ \\
\hline A & $90.80 \pm 0.21$ & $322.90 \pm 7.30$ & $3.62 \pm 0.14$ & $719.93 \pm 85.25$ & $7.90 \pm 0.06$ & $9.38 \pm 0.91$ \\
B & $139.93 \pm 13.01$ & $322.53 \pm 27.80^{\mathrm{a}}$ & $4.12 \pm 0.02^{\mathrm{a}}$ & $1101.33 \pm 72.52^{\mathrm{a}}$ & $7.90 \pm 0.12$ & $17.30 \pm 1.73$ \\
C & $363.60 \pm 60.32$ & $527.66 \pm 42.18^{\mathrm{ab}}$ & $3.91 \pm 0.11^{\mathrm{a}}$ & $1275.66 \pm 175.21^{\mathrm{a}}$ & $8.00 \pm 0.24$ & $8.21 \pm 0.73^{\mathrm{b}}$ \\
E & $351.25 \pm 23.15^{\mathrm{a}}$ & $395.80 \pm 0.57^{\mathrm{c}}$ & $3.91 \pm 0.01^{\mathrm{ab}^{\mathrm{b}}}$ & $660.00 \pm 1.15^{\mathrm{bc}}$ & $7.50 \pm 0.44$ & $10.70 \pm 0.05^{\mathrm{b}}$ \\
G & $96.56 \pm 5.21^{\mathrm{c}}$ & $273.13 \pm 19.48^{\mathrm{c}}$ & $3.71 \pm 0.03^{\mathrm{b}}$ & $686.00 \pm 27.73^{\mathrm{bc}}$ & $7.10 \pm 0.85^{\mathrm{a}}$ & $6.20 \pm 0.26^{\mathrm{ab}}$ \\
I & $73.80 \pm 1.61^{\mathrm{c}}$ & $256.35 \pm 3.92^{\mathrm{bc}}$ & $3.59 \pm 0.10^{\mathrm{b}}$ & $541.00 \pm 13.27^{\mathrm{bc}}$ & $7.30 \pm 0.09$ & $10.40 \pm 0.41^{\mathrm{b}}$ \\
LSD & 212.14 & 52.01 & 0.24 & 219.96 & 0.51 & 2.68 \\
\hline
\end{tabular}

Means tagged with superscript 'a' are significantly different compared to Normal Control at $p<0.05$

Means tagged with superscript ' $b$ ' are significantly different compared to Standard Drug at $p<0.05$

Means tagged with superscript ' $c$ ' are significantly different compared to $\mathrm{CCl}_{4}$ at $\mathrm{p}<0.05$

Means tagged with superscript a, b and 'c' are significantly different compared to Normal control, Standard Drug and $\mathrm{CCl}_{4}$ at $\mathrm{p}<0.05$; value are Mean \pm SEM

KEY:

Groups $(\mathrm{A}) \quad=\quad$ Normal Control (distilled water)

Groups $(\mathrm{B}) \quad=\quad$ Standard Drug (silymarin)

Groups $(\mathrm{C}) \quad=\quad \mathrm{CCl}_{4}$,

Groups $(\mathrm{E}) \quad=\quad 250 \mathrm{mg} / \mathrm{Kg}($ Bark $)+\mathrm{CCl}_{4}$,

Groups $(\mathrm{G}) \quad=\quad 500 \mathrm{mg} / \mathrm{Kg}($ Bark $)+\mathrm{CCl}_{4}$,

Groups $(\mathrm{I}) \quad=\quad 1000 \mathrm{mg} / \mathrm{Kg}($ Bark $)+\mathrm{CCl}_{4}$

LSD=Least Standard Deviation

Effect of the Stem Bark Extract of Carissa edulis on Lipid Profile Parameters of rats treated with $\mathrm{CCl}_{4}$

There was significant difference in TRIG, HDL and CHL level between the treatment groups observed at $\mathrm{P}<0.05$. For TRIG, there was significant increase in the value of TRIG, in $\mathrm{CCl}_{4}$ group compared to the normal control group. The TRIG level in other groups were significantly lower than the $\mathrm{CCl}_{4}$ group except $1000 \mathrm{mg}$ of the bark extract group which has the same level with $\mathrm{CCl}_{4}$ group.

For HDL, the highest concentrations were observed in $\mathrm{CCl}_{4}$ group and $1000 \mathrm{mg}$ of the bark extract group. The least values were observed in normal control group at $(0.9 \pm 0.15)$ and silymarin group $(0.96 \pm 0.19)$.

For CHL, there was a significant increase between the normal control group and the $\mathrm{CCl}_{4}$ group. At doses of $500 \mathrm{and} 1000 \mathrm{mg} / \mathrm{kg}$ of stem bark extracts there was a significant decrease in $\mathrm{CHL}$ level compared to the $\mathrm{CCl}_{4}$ group.

Table 5: Effect of the Ethanolic Stem Bark Extract of Carissa Edulis on Lipid Profile(TRIG, HDL and CHL) of Rats Treated with $\mathrm{CCl}_{4}$

\begin{tabular}{llll}
\hline Treatments & TRIGmmol/L & HDLmmol/L & CHLmmol/L \\
\hline A & $0.77 \pm 0.05$ & $0.91 \pm 0.15$ & $1.57 \pm 0.09$ \\
B & $0.82 \pm 0.07$ & $0.96 \pm 0.19$ & $1.91 \pm 0.21^{\mathrm{a}}$ \\
$\mathrm{C}$ & $1.06 \pm 0.01^{\mathrm{ab}}$ & $1.53 \pm 0.01^{\mathrm{a}}$ & $1.82 \pm 0.03^{\mathrm{a}}$ \\
$\mathrm{E}$ & $0.88 \pm 0.01^{\mathrm{c}}$ & $1.17 \pm 0.04^{\mathrm{c}}$ & $1.72 \pm 0.00$ \\
$\mathrm{G}$ & $0.97 \pm 0.02^{\mathrm{ab}}$ & $1.23 \pm 0.06^{\mathrm{abc}}$ & $1.39 \pm 0.02^{\mathrm{bc}}$ \\
$\mathrm{I}$ & $1.17 \pm 0.05^{\mathrm{ab}}$ & $1.33 \pm 0.08^{\mathrm{ab}}$ & $1.30 \pm 0.08^{\mathrm{abc}}$ \\
LSD & 0.12 & 0.27 & 0.24 \\
\hline
\end{tabular}

Means tagged with superscript 'a' are significantly different compared to Normal Control at $p<0.05$

Means tagged with superscript ' $b$ ' are significantly different compared to Standard Drug at $p<0.05$

Means tagged with superscript 'c' are significantly different compared to $\mathrm{CCl}_{4}$ at $\mathrm{p}<0.05$ 
Means tagged with superscript a, b and ' $\mathrm{c}$ ' are significantly different compared to Normal control, Standard $\mathrm{Drug}$ and $\mathrm{CCl}_{4}$ at $\mathrm{p}<0.05$; value are Mean \pm SEM.

Effects of the Stem Bark Extracts of Carissa edulis on Liver Antioxidant Parameters of Rats Treated with $\mathrm{CCl}_{4}$

There was a significant difference in all antioxidant parameters within treatment groups at $(\mathrm{P}<0.05)$. In malondialdehyde the highest value was observed in the $\mathrm{CCl}_{4}$ group $(11.8 \pm 0.11)$ compared to other groups. There was a significant decrease in malondialdehyde level in all the three concentrations of the stem bark extract in a dose dependent manner. For Glutathione, the highest level was observed in the normal control group $(85.32 \pm 1.66)$ which was significantly higher than the other treatment group, the least value of glutathione was observed in the $\mathrm{CCl}_{4}$ group (44.75 \pm 0.28$)$. There was a significant increase in glutathione level in the three concentrations of the stem bark extract groups compared to the $\mathrm{CCl}_{4}$ group.

For catalase the highest level was observed in the normal control group, while the least was observed in the $\mathrm{CCl}_{4}$ group at $(0.0013 \pm 0.000)$. There was a significant increase in catalase level in the animals treated with the three concentrations in each cases of the stem bark extract.

In superoxide dismutase, the least value was recorded in the $\mathrm{CCl}_{4}$ group (1.9886 \pm 0.003$)$. There was also a significant increase in superoxide dismutase level among animals treated with the three concentrations of the stem bark extracts.

Table 6:Effect of the Ethanolic Stem Bark Extract of Carissa Edulis on Liver Antioxidant Parameters of Rats treated with CCl

\begin{tabular}{llll} 
& Table 6:Effect of the Ethanolic Stem Bark Extract of Carissa Edulis on Liver Antioxidant Parameters of Rats & CatalaseU/g Hb \\
\hline Treatment & Malondialdehydenmol/g & Glutathione mol/g & $0.0043 \pm 0.0011$ \\
B & $8.52 \pm 0.07$ & $88.33 \pm 1.66$ & $0.0042 \pm 0.0031$ \\
C & $9.71 \pm 0.17^{\mathrm{a}}$ & $83.00 \pm 2.86^{\mathrm{a}}$ & $0.0013 \pm 0.0000^{\mathrm{ab}}$ \\
$\mathrm{E}$ & $11.81 \pm 0.11^{\mathrm{ab}}$ & $44.75 \pm 0.28^{\mathrm{ab}}$ & $0.0029 \pm 0.0001^{\mathrm{abc}}$ \\
$\mathrm{G}$ & $11.05 \pm 0.35^{\mathrm{abc}}$ & $57.00 \pm 0.44^{\mathrm{abc}}$ & $1.9927 \pm 0.0005$ \\
I & $9.18 \pm 0.19^{\mathrm{abc}}$ & $59.05 \pm 1.22^{\mathrm{abc}}$ & $0.0029 \pm 0.0003^{\mathrm{abc}}$ \\
LSD & $8.50 \pm 0.03^{\mathrm{bc}}$ & $76.70 \pm 1.93^{\mathrm{abc}}$ & $0.0051 \pm 0.0001^{\mathrm{abc}}$ \\
\hline
\end{tabular}

Means tagged with superscript 'a' are significantly different compared to Normal Control at $p<0.05$

Means tagged with superscript ' $b$ ' are significantly different compared to Standard Drug at $p<0.05$

Means tagged with superscript 'c' are significantly different compared to $\mathrm{CCl}_{4}$ at $\mathrm{p}<0.05$

Means tagged with superscript a, b and ' $\mathrm{c}$ ' are significantly different compared to Normal control, Standard $\mathrm{Drug}$ and $\mathrm{CCl}_{4}$ at $\mathrm{p}<0.05$; value are Mean.

Figure 1-6: Shows a histopathological observation of the liver after administering different doses of the extract in $\mathrm{CCl}_{4}$ treated rats.

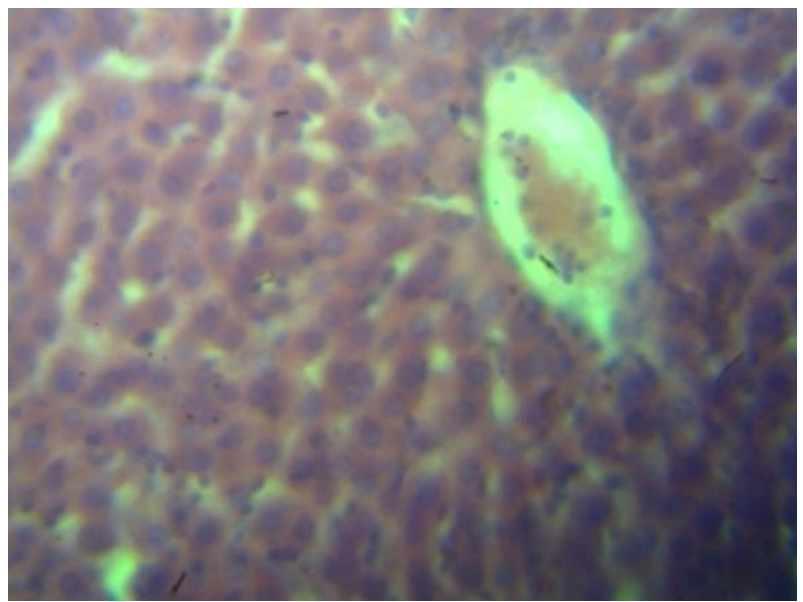

Fig.1: Cross Section of Normal Control

Figure 1: Shows the liver section of a control rat's normal nuclei presence of Kupffer cells within the sinusoids and also normal radical arrangement of the hepatocyte.

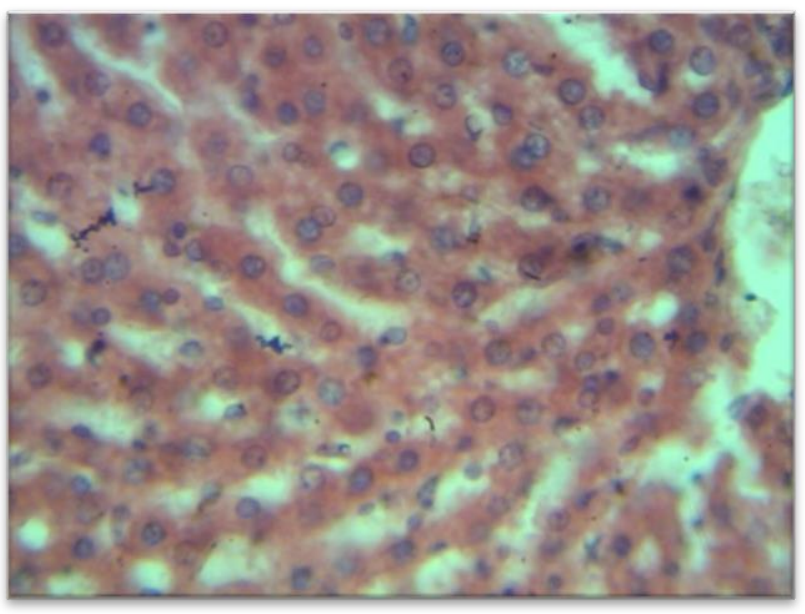

Fig. 2: Cross Section of the Rat Liver Treated with Silymarin. 
Figure 2: Shows the liver section of a rat after the standard drug silymarin $(50 \mathrm{mg} / \mathrm{kg})$ was administered with mild enlarged nuclei within the hepatocytes and a normal radial arrangement of hepatocytes with presence of Kupffer cells.

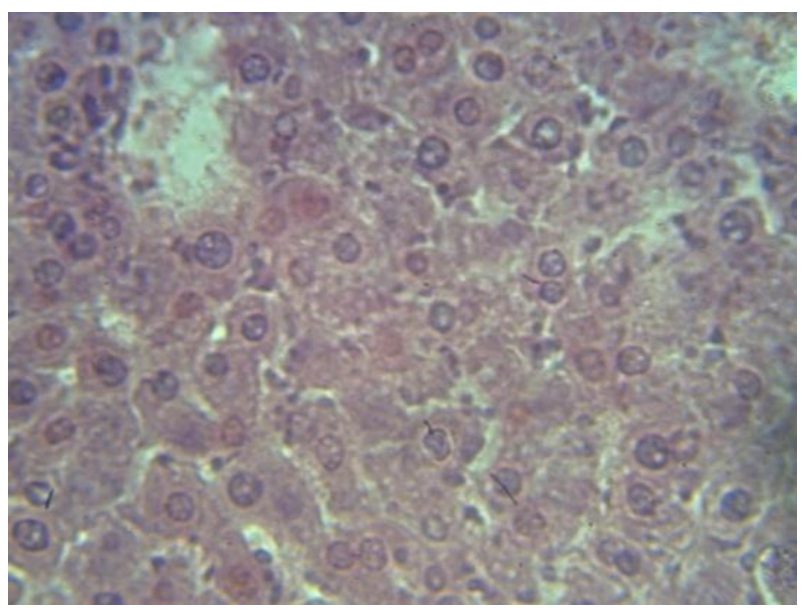

Fig.3: Cross Section of $\mathrm{CCl}_{4}$ Group.

Figure 3: shows the section of the liver of $\mathrm{CCl}_{4}$ group of animals which exhibited necrosis, intense congestion, and massive enlargement of the nuclei with alteration of the radial arrangement of hepatocytes.

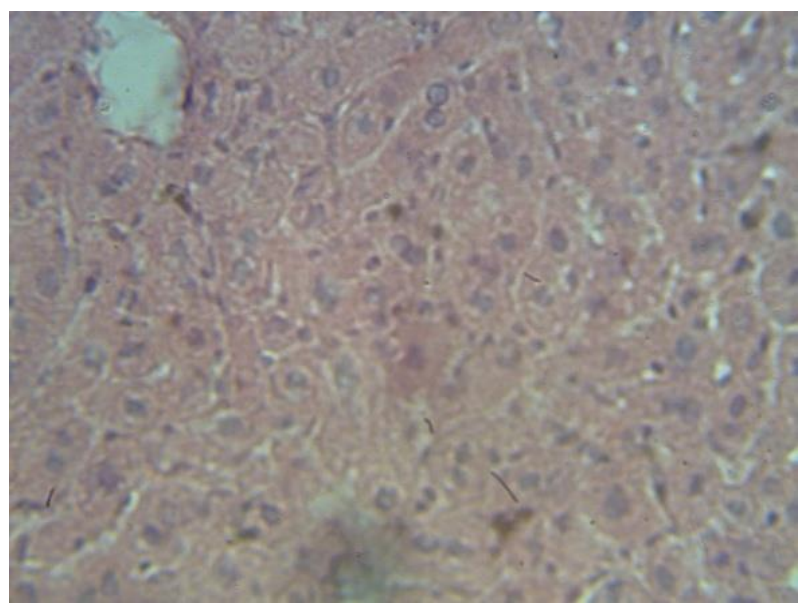

Fig. 4: Cross Section of 250mg per kg Stem Bark Extract.

Figure 4: Shows the section of a rat's liver after $250 \mathrm{mg} / \mathrm{kg}$ of the bark extract was administered with massive alteration of radial arrangement of hepatocyte and karyorrhexis of the nuclei.

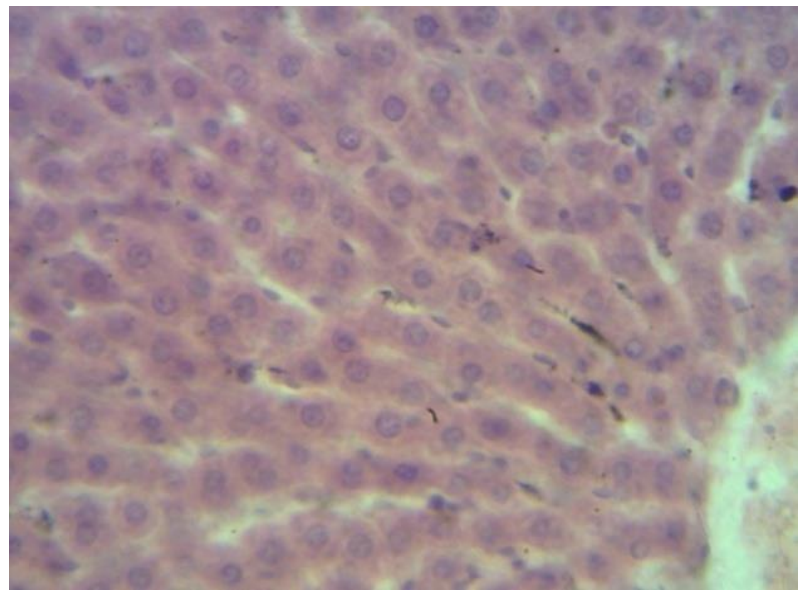

Fig. 5: Cross Section of the Rat Liver Treated with 500mg of Stem Bark Extract.

Figure 5: Shows the liver section of a rat after administering $500 \mathrm{mg} / \mathrm{kg}$ of the bark extract with massive enlargement of nuclei, karyoclasia and distortion of the radial arrangement of hepatocyte with few Kupffer cells within the sinusoids. 


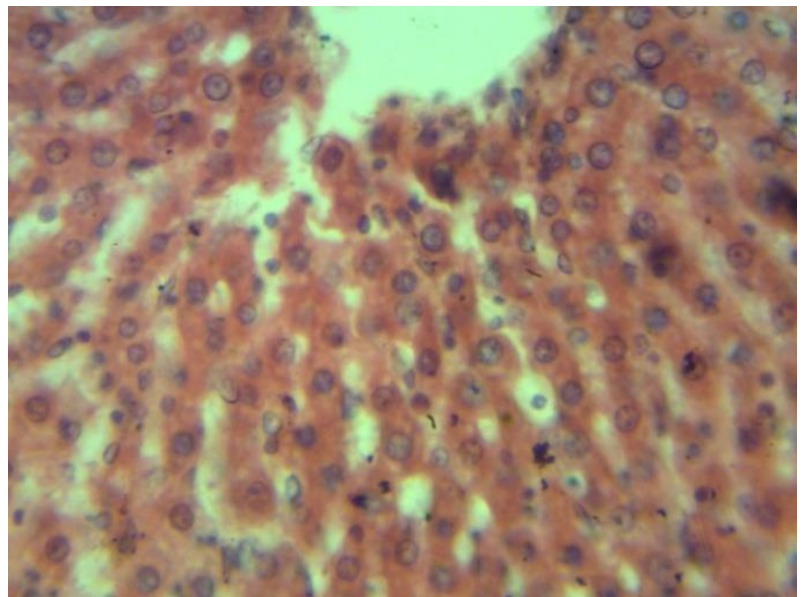

Fig. 6: Cross Section of the Rat Liver Treated with 1000mg of Stem Bark Extract.

Figure 6: Shows the liver section of a rat after administrating $1000 \mathrm{mg} / \mathrm{kg}$ of the bark extract with massive enlargement of nuclei within the hepatocytes and mild distortion of the radial arrangement of hepatocytes with presence of Kupffer cell.

\section{Discussion}

The presence of flavonoids, saponins and tannins in the ethanolic bark extracts of Carissa edulis was established by phytochemical analysis, and these compounds are reported to have antioxidant properties (Shankar et al., 2005).

The possible hepatoprotective property underlying Carissa edulis may be attributed to the antioxidant constituents, the plants most frequently used to treat liver disorders are Curcuma longa (turmeric), Glycyrrhizin glabra (Licorice) and Camellia sinesis (green tea), and they are all reported to be hepatoprotective due to the dominant antioxidative properties (Donatus et al., 1990, Soni et al., 1992, Wang \& Han 1993, Miyagawa et al., 1997).

The mechanism of the antioxidant property of Carissa edulis extracts has been stipulated to be due to the reduction of free radicals and also scavenging of reactive oxygen species and other free radicals (Woode et al., 2007).

The $\mathrm{LD}_{50}$ of the plant stem bark extract was established to be greater than $5000 \mathrm{mg} / \mathrm{kg}$ following oral administration in rats and according to the Hodge and Sterner Scale (CCOHS 2013). The ethanolic stem bark extract of Carissa edulis plant is said to be practically nontoxic.

An increase in body weight in the duration of the treatment period is indications of protection against hepatic injury while a decrease implies Hepatotoxicity (Pingale et al., 2008). There was no clear pattern on the impact of the extract on body weight; under this circumstance it will be difficult to know the exact impact of the treatment on body weight hence the need for further research on this area.

On liver function indices, the data showed a significant increase in the activities of Aspartate aminotransferase (AST), Alkaline phosphatase (ALP) and Alanine aminotransferase (ALT) after exposure to $\mathrm{CCl}_{4}$ at $\mathrm{P}<0.05$ in rats. This outcome is consistent with many authors who reported that these enzymes levels are significantly elevated after $\mathrm{CCl}_{4}$ administration (Mehmetcik et al., 2008, Aric \& Cetin 2011, Tin et al., 2011). Treatment with the ethanolic stem bark extract showed a dose dependent \& significant protection to the rats against $\mathrm{CCl}_{4}$ induced liver injury at $\mathrm{P}<0.05$.

Studies have revealed that $\mathrm{CCl}_{4}$ administration causes an elevation in bilirubin level owing to its toxicity (Recknagal 1967). However, the result of this study revealed that $\mathrm{CCl}_{4}$ did not produce an increase in bilirubin level as expected. This is probably due to environmental factors, age and nutritional factors (Hale 1983, Schwetner 1994, Buyakasik et al., 2008).

For total protein, studies have shown that, there is a decrease in the level of total protein due to hepatic intoxication (Recknagal 1967). Also an increase in the protein level signifies hepatoprotective activity as it speeds up the regeneration and production of liver cells (Mahheswari \& Rao 2005). Contrary to this expectation, the induction of liver injury using $\mathrm{CCl}_{4}$ did not produce a reduction in the level of total protein probably due to factors like, the animal state of hydration, chronic infection and inflammation or humoral immunodeficiency (Ciszewski et al., 1993).

Previous studies reported that $\mathrm{CCl}_{4}$ causes reduction in albumin level (Fahim et al., 1999, Khan \& Alzohairy 2011, Althnaian 2013). Administration of $\mathrm{CCl}_{4}$ causes hepatic changes which leads to rapid loss of the capability of the liver to synthesize albumin since albumin is produced on a polysome bound to the endoplasmic reticulum (Redman 1969, Hicks et al., 1969). The result of this study showed significant increase in albumin level in about $50 \%$ of the extract treated groups, this shows the ability of the extract to stimulate the synthesis of albumin.

There was a significant difference in the lipid profile (HDL, CHL, and TRIG) levels between the treatment groups observed at $\mathrm{P}<0.05$. The values of Triglyceride for all the groups were lower than the $\mathrm{CCl}_{4}$ group with significant reduction at $500 \mathrm{mg}$ and $1000 \mathrm{mg} / \mathrm{kg}$ of the stem barks extract groups. An increase in membrane Cholesterol is associated with a decrease in membrane functions as well as changes in membrane receptor, enzyme accessibility and their activation (Emerole \& Thabrew 1983). The ability of the extracts to reverse the abnormality may suggest that the extract has the potential to decrease serum CHL in hypercholesterolemia.

In the case of High Density Lipoprotein (HDL), 500 and 1000mg of the stem bark extract produced a significant increase in HDL level compared to the normal control group. However, the highest level of HDL was observed in the $\mathrm{CCl}_{4}$ group, this elevation is not consistent with most findings probably because HDL is more strongly controlled by genetic factors than other lipoproteins Yamashita et al., 2000).

For liver antioxidant parameters, a decrease in the level of antioxidant enzymes and increase in lipid per oxidation level were noticed after the $\mathrm{CCl}_{4}$ administration (Camp et al., 2003). This finding demonstrated the effectiveness of Carissa edulis extract in averting $\mathrm{CCl}_{4}$ Hepatotoxicity by enhancing the activity of the liver SOP, Catalase and Glutathione enzymes while reducing the liver MDA content. This may be ascribed to the presence of the several compounds which posses high antioxidant activities that scavenge the product radicals (Daspupta et al., 2004). 
The histopathological studies also provided important evidence supporting the biochemical analysis and liver antioxidant status. At doses of $500 \mathrm{mg}$ and $1000 \mathrm{mg}$ of the extracts there was a distinct recovery from the structural damage caused by $\mathrm{CCl}_{4}$ which is comparable to the standard drug silymarin. This indicates pronounced protection to the liver.

\section{Conclusion}

This study demonstrated the protective effect of Carissa edulis ethanolic stem bark extract against $\mathrm{CCl}_{4}$ induced liver injury in rats. This may be due to the presence of some endogenous substance with antioxidant and detoxifying properties. The active compounds responsible for the hepatoprotective activity have not been identified in this study. The mechanism of action also remained unproven. Hence the need for further research to identify the constituents of the tested plant responsible for the hepatoprotective effect.

\section{Acknowledgement}

Professor John C. Aguyi, Mentoring, guidance and social support Mr. Luka Wazoh, Mr. Azi Sunday and Mr. DA Bulus technical support

\section{References}

[1] Adil M, Allahveidiyev N \& Olga NO (2003). Fighting Multidrug Resistance with Herbal Extracts, Essential Oils and their components Science Direct.

[2] Ahmad J \& Odin J (2017). Epidemiology and Genetic risk factors of Drugs Hepatotoxicity. Clinical Liver Diseases 2(1), 5572.https://doi.org/10.1016/j.cld.2016.08.004.

[3] Althnaian TI, Albokhadaim EI \& Bahr SM (2013). Biochemical and Histopathological Study in Rats Intoxicated with carbon tetrachloride and Treated with Camel milk. Springer Plus, 2, 57-64.https://doi.org/10.1186/2193-1801-2-57.

[4] Alyoussef H \& Hassan W (2010).Phytochemical and Biological Studies of the aerial parts of Carissa edulis growing in Saudi Arabia Bioscience. Biotechnology Research Asia, 7(2), 625-646.

[5] Arici OF \& Cetin N (2011). Protective role of gurclin against carbon tetrachloride (CCl4) induced coagulation disturbances in rats. Regulatory Peptides, 16(6), 139-142.https://doi.org/10.1016/j.regpep.2010.10.009.

[6] Banker GJ \& Vernma SK (1987). Preliminary studies of flowering and fruiting in Carissa edulis, Journal of Natural Product, 4(7), 10-57.

[7] Bjornsson ES (2015). Drug induced Liver Injury an overview over the most critical compound. Archive of Toxicology, 8(9), 327334.https://doi.org/10.1007/s00204-015-1456-2.

[8] Bjornsson ES, Bergman OM, Bjornsson HK, Kvaran RB \& Olafsson S (2013). Incidence Presentation and Outcomes in patients with Drugs Induced Liver Injury in General Population in Iceland, Gastroenterology, 14(4), 1419-1425.https://doi.org/10.1053/j.gastro.2013.02.006.

[9] Burkil HM (1985). The useful plants of West Africa, Second edition, Vol/families. A-D. Royal Botanical Gardens. London: Kew

[10] Buyakasik Y,Goker H, Buyakasik NS, Sayinalp N, Hasnedaroglu IC \&Ozcebe OI (2008).Effect of platelet count on secretion capacity formulization and use of formulae for evaluation of platelets secretion in thrombocytopenic patients. Blood Coagulation Fibrinolysis, 1(9), 633637.https://doi.org/10.1097/MBC.0b013e32830bfdac.

[11] Camp L, Benilde B, Anna RG, Robert JA, Jones LM,Claudia O \& Senthilkumar S (2004). (Eds). Reports of the thematic strategy for soil protection Volume introduction and executive summary. EUR 2B1 EN/1.

[12] Canadian Centre for Occupational Health and Safety (2013). What is LD50 and LC50? Retrieved October 8, 2015, from Canadian Centre for Occupational Health and safety websites http://www.ccohs.ca/oshanswer/chemicals/id50.html.

[13] Chalassani N, Fontana RJ \& Bonkovsky HL (2008). Causes Clinical Features and Outcomes from a Prospective Study of Drug Induced Liver Injury in the United States Gastroenterology 135: 1924- 1934.https://doi.org/10.1053/j.gastro.2008.09.011.

[14] Ciszewski TS, Ralston S, Acheson D, Wasi S \& Strong SJ (1993). Protein level and plasma-phoresis. Intensity Transfusion Medicine 3, 5965.https://doi.org/10.1111/j.1365-3148.1993.tb00105.x.

[15] Daspupta A, Ramsey KL, Smith JS \& Auble DT (2004). Sir antagonist 1 (San1) is a unbiquintinligase. Journal of Biological Chemistry, 278(26), 26830-26838.https://doi.org/10.1074/jbc.M400894200.

[16] Deng J, Ding C, Zhang L, Yang R \& Zhou Y (2009). Authentication of three related herbal species (Curcuma) by DNA bar-coding. Journal of Medicinal Plant Research, 5(28), 6401-6406.

[17] Donatus IA, Sardjoko TA \& Verneuten NP (1990). Cytotoxic and Cytoprotective activities of Curcumin. Effects on Paracetamol induced cytotoxicity, lipid peroxidation and glutathione depletion in rat's hepatocytes. Biochemical Pharmacology. 3(9), 1869-1875.https://doi.org/10.1016/00062952(90)90603-I.

[18] Emerole GO \& Thabrew M (1983). Changes in some rat hepatic microsomal components induced by prolonged administration of Chloroquine. Biochemical Pharmacology,32(20), 3005-3009.https://doi.org/10.1016/0006-2952(83)90241-1.

[19] Fahim FA, Estmat AY, Fadel HM \& Hassan KF (1999).Allied studies on the effect of Rosmarinus officinalis (LINN) on experimental hepatotoxicity and mutagenesis. International Journal of Food Science and Nutrition, 50, 413-427.https://doi.org/10.1080/096374899100987.

[20] Frenzel C \& Teschke R (2016). Herbal Hepatotoxicity Clinical Characteristics and Listing Compilation. International Journal of Molecular Sciences. $1(7), 50-88$

[21] Friedman KL, Heit JJ, Long DM \& Chechm TR (2003).1-13 N-terminal domain of yeast telomerase reverse transcriptase: recruitment of Ests3p to telomerase complex. Molecular Biology of the Cell,14(1), 1-13.https://doi.org/10.1091/mbc.e02-06-0327.

[22] Hale JM (1983). The action of hydrogen sulfide on paleographic oxygen sensors. Aquatic and physiological applications. Gnaiger, E., Forstner, H. (Eds), Springer, Berlin, Heidelberg, New York: 73-75.

[23] Hanan AY \& Hassan WH (2010). Phytochemical and Biological Studies of Aerial Parts of Carissa edulis growing in Saudi Arabia Biosciences Biotechnology Res. Asia: 635-646.

[24] Hicks LE, Langham RA \& Takenaka J (1969). Formation of membrane bound polyribosomes. American Journal of Public Health.2(1), 202 - 777.

[25] Hutchinson J \& Dalziel JM (1963). Flora of West Africa. Vol. II Crown agents for oversea government and administration, London: Mill-Banks.

[26] Ibrahim H (1997). Pharmacognostic \& biological analgesic activity studies of Carissa edulis Vahl Ph.D. Ahmadu Bello University Zaria, Nigeria. $157-160,235-245,306-307$.

[27] Irvine FR (1961).Woody plants of Ghana, London: Oxford Press 616-618.

[28] Ishida Y, Kondo T, Ohshimat FF, Wara HI, Wakura Y \& Mukaida NA (2002).Pivotal involvement of IFN gamma, in the pathogenesis of acetaminophen induced liver injury, Federation of America Societies for Biology Journal, 1(6), 1227-1236.https://doi.org/10.1096/fj.02-0046com.

[29] Kebeinei JS, Ndalut \& PK Sabah A (2011). Antiplasmodial activity of Nortrachetogenin from the root bark of Carissa edulis (Vahl). International Journal of Applied Research in Nigeria. 2(1), 145-148.

[30] Khan AA \& Alzohairy M (2011). Hepatoprotective Effect of Camel Milk against CCl4 induced hepatotoxicity in Rats. Asian Journal of Biochemistry, 6(2), 171-180.https://doi.org/10.3923/ajb.2011.171.180.

[31] Lee Y (2003). The technology acceptance model: Past, Present and Future. Communications of the Association for Information Systems Volume 12. University of Colorado at Boulder, Younghwa. Lee@ colorado.edu. https://doi.org/10.17705/1CAIS.01250. 
[32] Li R, Guo N, Nfu Z, Ding G,Zou Y \& Wang Z (2011).Hepatoprotective actions of radix paenial rubre, aqueous extract against CCl4 induced hepatic damage. Molecules, 1(6), 8684-8693.https://doi.org/10.3390/molecules16108684.

[33] Mahheswari MU \& Rao PGM (2005). Antihepatoprotective effects of grape seed in Rats. Indian Journal of Pharmacology, 37(3), 179.https://doi.org/10.4103/0253-7613.16216.

[34] Marie S (2015). Toxic Not Healthy: Surprising Liver Dangers of Herbal Products. Everyday Health Digestive Health Hepatitis C https:// www.everyday healthcom.

[35] Masubuchi, Y, Bourdi M, Reilly TP, Graf ML, George JW \&Pohll LR (2003). Roles of interleu-kin-6 in hepatic heat shock protein expression and protection against acetaminophen induced liver disease. Biochemical and Biophysical research Communications, 304, 207212.https://doi.org/10.1016/S0006-291X(03)00572-2.

[36] McNally T \& Peter C (2006). New York State Law Reporting Bureau, Appellate Division Second Department, NY Slip OP 04811 (30 AD3d 482).

[37] Mehmetcik G, Ozdemirier G, Kocak-Toker N, Cevikbas U \& Uysal M (2008). Effect of pretreatment with artichoke extract on carbon tetrachloride induced liver injury and oxidative stress. Experimental Toxicology Pathology, 60(6), 475-480.https://doi.org/10.1016/j.etp.2008.04.014.

[38] Miyagawa C, Wu C \& Kennedy DO (1997). Protective effects of green tea extract and tea polyphenol against cytotoxicity of 1.4 - naphthoquinone in isolated rate hepatocytes. 12(7), 61-190.https://doi.org/10.1271/bbb.61.1901.

[39] Oliver B (1960). Medicinal plants in Nigeria published as a private edition by the Nigerian College of Arts Sciences and Technology 1960 page 52.

[40] Omino FA \& Kokwaro JO (1993). Ethno botany of Apocynaceae species in Kenya. Journal of Ethno Pharmacology 4(1), 167-180. https://doi.org/10.1016/0378-8741(93)90065-D.

[41] Ostapowicz G, Fontana RJ, Schiodt FV, Larso A, Davern TJ, Han SH \& Lee WM (2002). Acute liver failure study group results of prospective study of acute liver failure at 17 tertiary care centers in the United States. Annals of Internal Medicine, 137(9), 947954.https://doi.org/10.7326/0003-4819-137-12-200212170-00007.

[42] Pantano F, Mannochi G, Marinelli E, Gentili S, Graziano S, Busardo FP \& Dilucas NM (2017).Hepatotoxicity Induced by greater Celandine (Chelidonium Majus. L.); A review of the Literature European Reviewed Journal of Medical and Pharmacological Sciences2(1), $2146-2152$.

[43] Pantano F, Tittarell R, Manocchi G, Zaami S, Ricci S, Giogetti R, Terranova D, Bustardo FP \& Marinelli E (2016). Hepatotoxicity Induced by the 3Ks Kava, Kratom and Khat. International Journal of Molecular Sciences 1(7), 50-88.https://doi.org/10.3390/ijms17040580.

[44] Pingale S, Raghunath DP \& Gdna S (2008). Standardization of herbal drugs as potent liver tonic apartment pharmacology online. Maharashtra India, 1, 13-19.

[45] Recknagal RO (1967). Carbon tetrachloride hepatotoxicity. Pharmacology Review, 1(9), 145-208.

[46] Redman D (1969).Reduction and Re oxidation of Purothionins. Journal of the Science of Food and Agriculture, 20, 9.https://doi.org/10.1002/jsfa.2740200908.

[47] Schwetner HA, Jackson WG \& Tolan G (1994). Association of low serum concentration of bilirubin with increased risk of coronary artery disease. Clinical Chemistry, 40(1), 18-22.https://doi.org/10.1093/clinchem/40.1.18.

[48] Saro C, Clinard F, Quarzir K, Chanay H, Allard C, Guillemin C, Lenoir C, Lemonier A \& Hilton P (2000). Incidence of drug induced hepatic injuries a French population-based study. Hepatology 3(6), 451-455.https://doi.org/10.1053/jhep.2002.34857.

[49] Shankar MB, Parikh JR, Geetha M, Mehta RS, \& Saluja AK (2005).Hepatoprotective activity of benzopyrone from Tephrosia purpuneapers. Journal of Natural Remedies, 5(2), 115-120.

[50] Sofowara A (1986). The state of medicinal plant research in Nigeria 1st edition. University Press Ltd Ife Nigeria pp. 145-148.

[51] Soni KB, Lahiri M \& Chackrodeo P (1992). Protective effect of food additives on aflatoxin induced mutagenicity and hepato-carcinogenicity, Cancer Letters, 115-121.

[52] Tin TS, Woodward A, Thorney S \& Ameratunga S (2011). Regional variation in pedal cyclist injuries in New Zealand: Safety in numbers of risk of coronary artery disease Clinical Chemistry, 40(1), 18-23.

[53] Trease GC \& Evans WC (1989). Pharmacognosy13th edition. ELBS/ Bailliere Tindall, London. Pages 345-346, 535-536, 772-773.

[54] Wang GS \& Han ZW (1993). The protective action of Glycyrrhizin flavonoids against carbon-tetrachloride hepatotoxicity in mice. Yoa Hsueh Hsueh Pao, 2(8), 572-576.

[55] Wood E, Ansahi C, Ainooson GK \& Abotsi WM (2007). Anti-inflammatory and antioxidants properties of the root extract of Carissa edulis (Forsk). Vahl (Apocynaceae). Journal of Science and Technology, 2(7), 3-4.https://doi.org/10.4314/just.v27i3.33054.

[56] Yamashita RA, Sellers JR \& Adeson JB (2000). Identification and analysis of the myosin super family in Drosophila: A database approach. Journal of Muscle Research and Cell Motility, 21(6), 491-505.https://doi.org/10.1023/A:1026589626422.

[57] Zephaniah U (2011). Tanzania halts miracle cure after 52 died. Daily Nation, Sunday March, 2011:23. 